\title{
De-Linking From Western Epistemologies: Using Guanxi-Type Relationships to Attract and Retain Hotel Guests in the Middle East
}

\author{
Ahmed Shaalan, ${ }^{1,3}$ Riyad Eid, ${ }^{2} \odot$ and Marwa Tourky ${ }^{3} \odot$ \\ ${ }^{1}$ Zayed University, UAE, ${ }^{2}$ United Arab Emirates University, UAE, and ${ }^{3}$ Cranfield University, UK
}

ABSTRACT Relationships are widely recognized as key to business success in the form of both informal interpersonal networks and formal organizational relationships. While Chinese personal networks (guanxi) have attracted scholars' interest, the concept has not been fully investigated or understood in other contexts, especially the Middle East, where personal networks fulfill some of the same roles. The underlying socio-cultural formulae of the distinctive cultural dimensions that influence relationship formation in the Middle East also remain under-explored. This research therefore investigates the dimensions of guanxi-type relationships in the Middle East and introduces a new model integrating these relationships into the existing relationship marketing framework, enabling firms to harness personal networks for organizational gain, in turn generating customer satisfaction and retention. Using empirical data from a survey of 637 hotel guests in 17 countries - drawn from a unique target population of guests introduced to Middle Eastern hotels via personal relationships - we show how guanxi-type relationships influence organizational relationships and improve satisfaction and retention. Our significant contributions to theory and practice include extending a holistic understanding of guanxi, enhancing knowledge of its dimensions in the Middle East, and providing managers with clear evidence for a hybrid system of guanxi-type and organizational relationships.

KEYWORDS guanxi, interpersonal relationships, Middle East, organizational relationships, tourism and hospitality industry

ACCEPTED BY Senior Editor Abby Jingzi Zhou

\section{INTRODUGTION}

It is widely accepted globally that establishing, developing, and maintaining quality relationships with customers is important when conducting business, especially in complex and highly competitive markets (Ndubisi \& Wah, 2005; Weir, Sultan, \&

Corresponding author: Riyad Eid (riyad.aly@uaeu.ac.ae)

This article has been updated since its initial publication. For details, see https://doi.org/10.1017/ mor.2021.57 
Van De Bunt, 2016). However, the way these relationships are nurtured and deepened varies in different cultures, with notable differences between the East and West (Fainshmidt, Judge, Aguilera, \& Smith, 2018; Flambard-Ruaud, 2005; Kabasakal \& Bodur, 2002; Weir et al., 2016; Yen, Yu, \& Barnes 2007). Challenging the dominant Anglo-Western-centric model is seen as essential, not least because it perpetuates the false belief in universality that remains prevalent in many areas of service research, particularly in tourism and hospitality (Tucker \& Zhang, 2016: 250). In an era of transforming economies and rapidly expanding markets, context-specific research becomes even more important, along with the need for Eastern knowledge and theory to be explored through the prism of different cultures (Chambers \& Buzinde, 2015). Some studies have begun the important task of uncoupling service research from Western epistemologies by focusing on guanxi-type relationships (Tucker \& Zhang, 2016: 250). Guanxi, a Chinese construct characterized by relationship-based networks, has been used by scholars to contextualize their discussions of relationship development in China (Luo, Huang, \& Wang, 2012). Many features of guanxi are not unique to Chinese society, but are present to some degree in every society in the world, including the Middle East (Hutchings \& Weir, 2006a, 2006b; Weir et al., 2016). The similarities between network-based relationships in China and those in the Arab world prompted Hutchings and Weir (2006a, 2006b) to call for research addressing networks in the Arab world generally and guanxi-type relationships specifically, given the lack of adequate research. Answering this call, Shaalan, Weir, Reast, Johnson, and Tourky (2014) found that similar relationships to those found in Chinese guanxi existed in the Middle East, and agreed with Weir and Hutchings (2005) that life in the Arab world was wholly reliant on networks of interpersonal connections. The overlapping features between Chinese and Middle Eastern networks include the benefits for business and indeed the need to use guanxi-type relationships to achieve business success (Shaalan et al., 2014). Accordingly, this study uses the term 'guanxi-type relationships' to refer to the networks of interpersonal ties found in the Middle East.

Despite the work already undertaken to understand the role of guanxi-type relationships, significant gaps in knowledge can be clearly identified. Firstly, exploration of the role of such relationships in cultures outside China has been limited, especially in non-Western cultures such as the Middle East. Secondly, the role of guanxi-type relationships in the specific context of the hotel sector has not been explored although the hotel sector is a relationship-intensive industry. Thirdly, there is a lack of studies on the interplay between guanxi-type relationships and relationship marketing, especially in the hotel and tourism context, where it could be highly significant given the potential effects on guest satisfaction and retention. Our extensive review and critical discussion of the extant literature provide a solid theoretical foundation and rationale for our study, since previous studies, while rich in detail, are not without gaps and problems. Firstly, the role of guanxi-type relationships in cultures outside China has attracted little attention, with only a few studies focusing on the West (e.g., Burt, 2019; Burt, Bian, \& Opper, 
2018), the Middle East (Berger, Herstein, McCarthy, \& Puffer, 2019; Hutchings \& Weir, 2006a, 2006b), or other developing states grounded in unique political, cultural, social, and economic settings. Li, Zhou, Zhou, and Yang (2019) support this view, arguing that further research on guanxi is needed not only in China but also in the emerging global context. The lack of studies on the Middle East has persisted despite substantial evidence of its unique business and cultural practices (Sharma, 2010). Middle Eastern culture has high collectivistic values and strong long-term orientation (Hofstede, 2001), making it culturally very distinct from the West. Furthermore, an extensive review by Samaha, Beck, and Palmatier (2014) of relationship marketing studies from 36 countries revealed great differences in the effects of relational mediators such as trust and customer satisfaction in different countries, contexts, and cultures.

Overall, inadequate attention has been paid to better understanding guanxitype networks and how they influence business in the Middle Eastern context (Hutchings \& Weir, 2006b). Berger and Herstein (2012) argue that a clearer understanding of the components and operation of guanxi-like relationships in the business world is essential in order to grasp its central importance in a culture where the first rule of business is socialization. Some scholars have specifically encouraged further research on guanxi-type relationships in the Middle East. For example, Weir et al. (2016) argue that, given the central importance of interpersonal relationships in collectivist cultures, their role in the development of relationship strategies should be explored.

Secondly, alongside this shortage of guanxi-based research in the culturallydistinct geographical context of the Middle East, there is a general lack of such studies in the specific context of the hotel sector despite its importance. Previous studies have focused on a range of fields such as marketing (Lee, Tang, Yip, \& Sharma, 2017; Shaalan, Reast, Johnson, \& Tourky, 2013), supply chain management (Geng, Mansouri, Aktas, \& Yen, 2017), organizational learning (Chung, Yang, \& Huang, 2015; Leung, Chan, Chung, \& Ngai, 2011), operation management (Wu \& Chiu, 2016), entrepreneurship (Chen, Chang, \& Lee, 2015; Phan, Zhou, \& Abrahamson, 2010), human resources management (Ren \& Chadee, 2017), and strategic management (Cao, Baker, \& Schniederjans, 2014). However, little is known about the role and impact of guanxi-type relationships in different cultures in the hotel industry. The few exceptions include Chen (2017), who contributed a contextual interpretation of guanxi, but only in the context of the development of Chinese tourism.

Thirdly, the interplay between guanxi-type relationships and relationship marketing remains under-researched, especially in the hotel and tourism context. The extent to which guanxi-type relationships could complement relationship marketing has not been fully understood, and no model has empirically integrated guanxi theory into the existing relationship marketing framework, even though many scholars have suggested the importance of this link (Björkman \& Kock, 1995; Geddie, DeFranco, \& Geddie, 2002, 2005; Shaalan et al., 2013). While the two phenomena are fundamentally different, a detailed understanding of the 
relationship between them is highly relevant to achieving specific business objectives. Some past research has shown that guanxi-type relationships can be considered an important strategic asset (Lee et al., 2017), while other studies have noted that the personal relationship between a potential customer and a firm's representative (employee or loyal customer) typically develops before a transaction occurs (Yau, Lee, Chow, Sin \& Alan, 2000). Some previous theoretical attempts have been made to compare and link guanxi-type relationships and relationship marketing (e.g., Geddie et al., 2002; Shaalan et al., 2013), but the exact nature of their dimensions and relationship remains unclear. This lack of knowledge has particular relevance in the hotel industry and other parts of the tourism and hospitality sector, given the potential impact on guest satisfaction and retention.

This study answers these calls for specific research in the Middle East, as well as filling the other gaps in the literature highlighted above. Overall, it seeks to advance understanding of guanxi as a holistic and global construct. This article addresses all these gaps in knowledge by exploring the role that guanxi-type relationships play in a non-Western context, focusing specifically on hotel guests in the Middle East who were introduced through interpersonal networks. This unique research population enables us to understand the role of guanxi-type relationships in attracting new guests, and the effect on customer satisfaction and retention. Importantly, we go beyond this to investigate how guanxi-type relationships fit into the existing framework of the relationship marketing framework in the Middle Eastern context, and to explore whether guanxi-type relationships can be transformed into organizational relationships, which in turn generate customer satisfaction and/or retention. To achieve these objectives, we develop and test a conceptual model using inputs from many well-established but diverse viewpoints. To our knowledge, this is the first study to seek to build a unified model integrating guanxi-type relationships into the relationship marketing framework.

In the following sections, we present the theoretical background of the main constructs, elaborate on research gaps, and introduce the proposed research model and hypotheses. The methods are then explained, followed by the presentation of the results of the data analysis and a discussion of the main findings. Finally, implications, limitations, and avenues for future research are presented in the conclusion.

\section{THEORETICAL BACKGROUND AND HYPOTHESES}

\section{Theoretical Foundations of Guanxi}

Establishing strong relationships with customers is regarded as key to business success in today's complex and highly competitive markets. One of the approaches used to achieve this is guanxi, a Chinese term denoting interpersonal networks that have considerable significance in most facets of relationships (Jia, You, \& Du, 2012). While guanxi is not sufficient by itself to persuade customers to buy products

(C) The Author(s), 2021. Published by Cambridge University Press on behalf of The International Association for Chinese Management Research 
(Tsang, 1998), it is a significant foundational element to business relationships, whose main aim is to retain customers (Tseng, 2007). It has been described as a 'Chinese cultural phenomenon' (Fan, 2002: 374) whose multiple meanings go beyond the closest English equivalents of 'relationship' or 'connection' (Huang, 2008: 468). For example, it can be used to refer to the relationship between people with shared characteristics, active and repeated contact between people, and infrequent, direct communication with a person (Bian, 1994: 974). Three distinguishing qualities have been observed: familiarity or intimacy, trust, and mutual obligation (Bian, 1997; Burt et al., 2018; Burt \& Burzynska, 2017; Burt \& Opper, 2017; Li et al., 2019).

Guanxi has been conceptualized in a number of ways in the literature, firstly as a relationship. For example, Alston (1989: 28) defines it as a special relationship between two persons with an unlimited exchange of favors, each of them being fully committed to the other; Osland (1990: 8) describes it as a special relationship between one person who needs something and another who has the ability to give something; and Yang (1988: 409) regards it as pre-existing relationships between classmates, people with shared origins and/or relatives, workplace superiors/subordinates, etc. A second set of conceptualizations regards guanxi as ties. Jacobs (1979) defines it as particularistic ties based on shared attributes, and Bian (2006: 312) describes it as a particular and sentimental tie with the potential to facilitate exchanges of favors between the connected parties. Bian (2018) identifies five types of guanxi ties (connectivity, sentimental connection, sentiment-derived instrumental ties, instrumental-particular ties, and obligational ties), which vary in form and significance depending on the situation. Guanxi has no formal network structure, but involves strong ties between family members, close kin, and long-term friends, who seek to protect each other from a hostile context (Burt \& Opper, 2017; Zhao \& Burt, 2018). A third conceptualization, viewing guanxi as a problem-solving mechanism, is offered by Fan (2002: 372), who views it as a process of social interactions between two individuals who may or may not have a special relationship: if one asks for assistance, the other provides it or seeks further assistance from other connections. Many authors support and use Fan's definition (e.g., Chen \& Chen, 2004; Luo, 2007; Zhang \& Zhang, 2006). Other interpretations have cast guanxi as interpersonal friendships (Ang \& Leong, 2000); interpersonal connections (Xin \& Pearce, 1996: 1641); reciprocal exchanges (Hwang, 1987); tight, close-knit networks, and a gate or pass (Yeung \& Tung, 1996: 54).

We adopt a broad definition of guanxi as an informal norm of interpersonal exchange that regulates and facilitates privileged access to sentimental or instrumental resources at the dyadic or network level (Bian, 2018; Li et al., 2019).

\section{Features of Guanxi}

A number of significant features underlie the cultivation, use, and preservation of guanxi. Guanxi networks are essentially social in nature (Arias, 1998; Björkman \& 
Kock, 1995). The origins of Chinese guanxi have been traced back to Confucian teachings and principles (Bian \& Ang, 1997; Kienzle \& Shadur, 1997), which take a long-term view of social interactions. Guanxi can therefore last a lifetime (Li et al., 2019) and can even pass from one generation to another if maintained (Luo, 2007). Guanxi is usually considered at the individual level (Chung, 2019; Tsang, 1998) with relationships built among people, not organizations. However, the use of guanxi at the organizational level has increased, since employees are increasingly encouraged to use their personal guanxi for organizational purposes (Luo, 1997). Context is highly relevant: giving a gift in one situation might be accepted as a customary practice, while in a different situation it might be seen as a bribe (Luo, 2007). Guanxi's utilitarian core, whereby favors can be exchanged as a result of interpersonal links (Bian, 2018), can operate at the organizational level, enabling organizations to benefit from each other's guanxi if there is complementarity of resources and a mutual strategic need (Luo, 2007; Zhang, Kimbu, Lin, \& Ngoasong, 2020). Guanxi can also be transferred to a third party, if one person in relationship with two others is willing to link them (Luo, 1997; Tsang, 1998). Members of guanxi networks are committed to each other through an unwritten but mutually understood code of equity and reciprocity (Luo, 1997; Zhang et al., 2020). Disrespecting this code or refusing to return a favor can seriously damage a person's social reputation, leading to loss of face (Luo, 1997). Overall, guanxi's multiple features are indicative of rich and comprehensive networks with both cultural and social elements.

\section{Guanxi-Type Relationships Outside China}

Many of the features of guanxi are not unique to Chinese society, but exist to some extent in all societies, including those in the Middle East (Hutchings \& Weir, 2006a, 2006b) and the West (Burt, 2019; Burt \& Burzynska, 2017). However, the ways in which these relationships are nurtured and developed vary considerably, with notable differences between East and West (Fainshmidt et al., 2018; Flambard-Ruaud, 2005; Kabasakal \& Bodur, 2002; Weir et al., 2016; Yen et al., 2007). Even Burt (2019: 31), who argues that such networks exist in China and in Western societies, highlights a significant substantive difference between them: those in China are more hierarchical and more family-centric than those in the West. Burt and Burzynska (2017: 221-222) support this distinction, arguing that Chinese and Western networks have significant differences, while both strongly featuring trust and achievement.

Guanxi-type relationships in the Middle East. In the Middle East context, guanxi-type relationships are different. The tribal framework is preeminent: Arabs' heavy reliance on these networks draws on historical cultural values and traditions which are totally different from networking in the West (ALHussan, Al-Husan, \& Alhesan, 2017; ALHussan, AL-Husan, \& Chavi, 2014). Arab society has been shown to

(C) The Author(s), 2021. Published by Cambridge University Press on behalf of The International Association for Chinese Management Research 
rely heavily on these networks (Cunningham \& Sarayrah, 1993; Cunningham, Sarayrah, \& Sarayrah, 1994; Hutchings \& Weir, 2006a, 2006b; Metcalfe, 2006; Weir \& Hutchings, 2005), which can be characterized as a strategy for exchanging benefits. The unique features of Arab networks, such as origins, closeness, characteristics, density of usage, etc., can be partly attributed to the specific characteristics and cultural factors of Middle Eastern societies (Barakat, 1993; Hutchings \& Weir, 2006a). Since families are viewed as the fundamental unit of a society (Barakat, 1993; Hutchings \& Weir, 2006a), their influence extends from basic decisionmaking (Barakat, 1993) to business and management practices (Hutchings \& Weir, 2006a, 2006b; Metcalfe, 2006), education, government, and society at large (ALHussan et al., 2017; Cunningham \& Sarayrah, 1993), and includes non-material gains such as licences, scholarships, parliamentary seats, and other benefits that 'might enhance the well-being or social status of a person seeking it' (Pawelka \& Boeckh 2004: 40). The powerful influence of tribal connections in the Arab world can also be seen in the way relationships are overseen and arguments resolved. Generally, social networks underpin this process too, with a delegate acting as mediator between tribes in dispute (Cunningham \& Sarayrah, 1993). People with significant wealth or power use social networks extensively with a focus on their ultimate goals (Cunningham \& Sarayrah, 1993). As Metcalfe (2006) observed: 'Working relations in the Arab world are influenced by the ability of an individual or an entity to be able to move in the right channels of power and influence to accomplish something'. This heavy dependence on tribal and family ties can be contrasted with Burt and Opper's (2017) findings from China that entrepreneurs' primary source of support was more likely to be long-standing contacts than relatives: around $90 \%$ of the contacts providing support in the first decade of a business were non-family members.

It can be argued that a further distinction between guanxi-type relationships in the Middle East and those in the West and China is the underpinning of Islamic ethics and values (Hutchings \& Weir, 2006a; Weir \& Hutchings, 2005: 92). In the Arab world, religion is a guide to action, as it determines action in every aspect of people's lives (Hutchings \& Weir, 2006a: 146). Most Arabs are Muslims, and Islam 'shapes people's mindsets and opinions at a very deep level in addition to being responsible for many of the behavioral patterns that can be observed throughout the region' (Al-Omari, 2003: 77). Likewise, the origins of Chinese guanxi networks have been traced back to Confucian teachings and principles which guided behavioral patterns (Bian \& Ang, 1997; Kienzle \& Shadur, 1997).

Overall, it can therefore be seen that social networks in the Arab world are significantly more important than mere connections: they are the route to securing individual and business benefits, and they are ubiquitous. The dimensions of guanxi-type relationships in general, and how they differ between Chinese and Middle Eastern cultures, are explored in the next section. 


\section{Dimensions of Guanxi-Type Relationships}

Many studies have discussed the dimensions of guanxi (Chen, 2001; Tsang, 1998; Wang, 2007; Yang, 1994; Yau et al., 2000), illustrating it as a multi-dimensional construct. While there is no agreement about its dimensions, there is wide recognition - albeit in a fragmented manner - that its six main variables are bonding, empathy, reciprocity, personal trust, face, and affection. These will therefore be used in this study.

Bonding. Bonding is a social or business practice that functions by means of commonalities and common backgrounds, which is used to eliminate doubt between parties (Yau et al., 2000). Its potential bases are kinship, fictive kinship, locality and dialect, workplace, and friendship (Kiong \& Kee, 1998: 77-79). While particularly strong ties have been noted among family groups and long-term friends (Burt \& Opper, 2017; Li et al., 2019; Zhao \& Burt, 2018), individuals with no common background can also develop relationships through collaboration and cooperation (Tsang, 1998).

Empathy. Empathy can be defined as the ability to understand someone else's desires and goals (Yau et al., 2000). It reduces barriers to relationship building and ensures people are willing to help others in need (Wang, 2007). Empathy is extremely significant within guanxi ties, since people want to fully understand their partners and their requirements. In the Chinese context, it focuses on the benefactor's behavior, guided by Confucian principles such as 'Do unto others as you wish done unto yourself' (Hwang, 1987). The same principles are embedded in Arab cultures, drawn from the teachings of Islam and Christianity. In a collectivist culture such as the Arab world, empathy is important to establish relationships and build trust before doing business (Al-Omari, 2009; Barakat, 1993; Weir, Sultan, \& Van De Bunt, 2019).

Reciprocity. Reciprocity refers to mutual assistance between network members without the need for compensation (Barnett, Yandle, \& Naufal, 2013; Berger, Silbiger, Herstein, \& Barnes, 2015). It aids long-term relationships as it enhances trust (El-Said \& Harrigan, 2009), as well as directly influencing business performance (Berger et al., 2015; Bian, 2018). A guanxi-type relationship carries the implicit potential of boundless exchanges of favors, and continues in the long term through a similarly implicit loyalty to others in the network, reflecting an informal code of reciprocity (Luo, 2007). A person who receives favors but gives none will lose face (Barnes, Yen, \& Zhou, 2011). Reciprocity is among the norms that extend the influence of guanxi beyond kinship networks and into wider social interactions (Bian, 2018). In a Chinese business relationship, one guanxi party is expected to provide support to another in difficulty, on the understanding that a return favor will be available when needed (Wang, 2007). In the Middle East, reciprocity 
ensures a positive outcome, reduces uncertainty, and creates value (Mohamed \& Mohamad, 2011).

Personal trust. Personal trust in the context of guanxi chiefly relates to establishing credibility via past history and reputation through the fulfilment of promises and obligations with mutual satisfaction and beneficial interactions (Kiong \& Kee, 1998; Yau et al., 2000). Trust can also be seen as an index by which to judge someone's moral integrity and an initial channel to enhance the relationship between two parties (Chen \& Chen, 2004). Generally, members of guanxi networks place great value in trust and credibility in both social and business contexts (Burt \& Burzynska, 2017; Burt \& Opper, 2017). By contrast, the level of interpersonal trust and the quality of relationships in the Middle East is determined largely by family origin (Ivens \& Pardo, 2007; Smith, Huang, Harb, \& Torres, 2012). In such collectivist cultures, personal trust is therefore important to establish relationships before business can proceed (Al-Omari, 2003, 2009; Barakat, 1993; Weir et al., 2019). In Arab culture overall, goodwill, trust, and mutual respect are worth more than what is written down (Al-Omari, 2009; Hutchings \& Weir, 2006a).

Face. Face has been described as the public image of a person's or one's own prestige and reputation (Tsang, 1998), and as social status attained by completing recognized social roles in a community ( $\mathrm{Li}$ et al., 2019). It is generated not by self-assessment but by the opinions of other people. Face can not only strengthen the exclusive attachment that members feel towards a guanxi network (Bian \& Ikeda, 2014), but can influence the way an entire network is viewed. Overall, face can be seen as a sort of moral norm whereby all members of a group seek to gain it in order to maintain the group's dignity. In Chinese guanxi, face plays a major role in the preservation of networks (Chen, 2001; Shou, Guo, Zhang, \& $\mathrm{Su}, 2011$; Tsang, 1998), and has clear relevance in the business context as well as in social and moral spheres. This is no less true in Middle Eastern culture, where it plays a key role in relationship building by emphasizing the notions of continuity and collaboration (Berger et al., 2015).

Affection. Affection is a significant dimension of guanxi, since networks rely on altruism, a desire to help people, and affection-based feelings such as sympathy, care, trust, and love in order to operate successfully (Bian, 2018). The feelings and emotional attachments that exist within guanxi networks frequently reflect members' closeness and the quality of the relationships between them: thus, it is a significant variable (Barnes et al., 2011; Wang, 2007). Yang (1994) highlights that emotional exchanges rather than obligations are key to guanxi. The significance of affection is not limited to Chinese networks; it is to be found across cultures and countries, including those in the Middle East. While its most intimate forms can expect to 


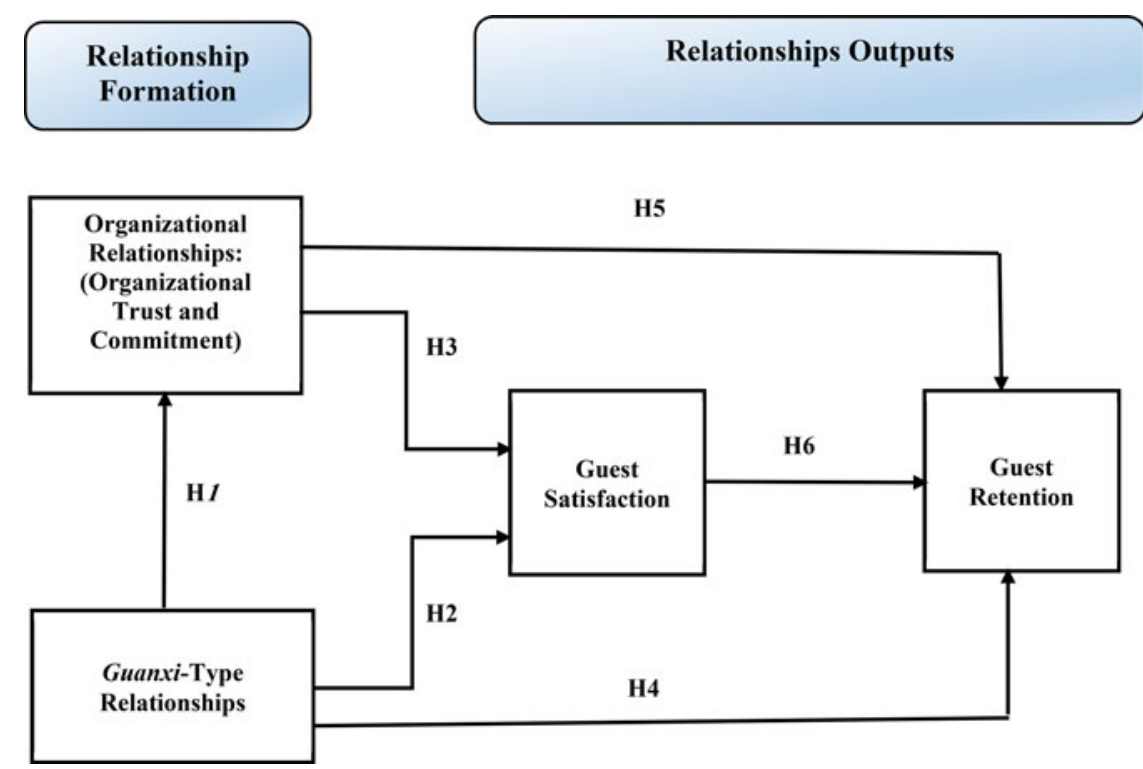

Figure 1. The research model

be found within families (Bian, 2018), it is possible to create affection even in a business relationship by investing in its development (Shou et al., 2011; Wang, 2007).

\section{Research Model and Hypotheses}

Guanxi and relationship marketing are different concepts with their own unique characteristics, benefits, and pitfalls (Geddie et al., 2005); however, the possibility of integrating them has long been mooted (Flambard-Ruaud, 2005; Tsang, 1998). While guanxi is an informal interpersonal relationship involving implicit mutual trust (Zhang \& Zhang, 2006), relationship marketing is a formal, official agreement defined and protected by a legal organizational framework. Prior research has inferred an association between them that would be important given its potential to improve customer recruitment and retention (Björkman \& Kock, 1995; Geddie et al., 2002, 2005). Other studies have recommended the importance of transferring guanxi-type relationships from the interpersonal to the organizational level (Flambard-Ruaud, 2005; Zhang \& Zhang, 2006).

The model we present in this research (Figure 1) is based on the premise that relationship marketing aims to attract, maintain, and enhance customer relationships (Berry, 2002), and that relationship marketing goes beyond the scope of guanxi (Zhang \& Zhang, 2006), since it helps retain customers by building organizational relationships (Tang, Chou, \& Chen, 2008). Initially, the model assumes that firms encourage all their employees to use their personal guanxi networks (e.g., family, friends, and colleagues) for organizational purposes (e.g., generating business and new customers) by rewarding them with commission or bonuses. Dunfee 
and Warren (2001) support this assumption, arguing that managers can use guanxitype relationships to access new customers. Since Arab people prefer to deal with those they already know, and consider that establishing a relationship before undertaking a business transaction is fundamental (Al-Omari, 2003, 2009; Berger et al., 2015; Berger et al., 2019; Hutchings \& Weir, 2006a), using guanxitype relationships can therefore be beneficial in the Middle Eastern context. This principle can be applied in many different business sectors, including the tourism and hospitality industry, where the relationship between a potential customer and a hotel's representative (employee) typically develops before a transaction occurs (Yau et al., 2000). Indeed, Flambard-Ruaud (2005) argues that in Asia, Africa, and the Middle East, successful business transactions are largely subject to established relationships.

Our proposed model therefore incorporates guanxi principles into existing relationship marketing processes, in essence using guanxi-type relationships to attract customers and relationship marketing to keep them. First, firms would engage all the components of guanxi (bonding, empathy, reciprocity, personal trust, face, and affection) to draw in clients, and, after an initial transaction, would apply relationship marketing programs to build organizational trust and commitment. The conversion of personal to organizational relationships is aimed at ensuring a long-term relationship with the customer, since promoting organizational trust and commitment increase customer retention (Bruhn, 2003), and retention contributes to long-term profits (Tseng, 2007). Several studies have highlighted the importance of this transfer (Barnes, Leonidou, Siu \& Leonidou, 2015; Zhang \& Zhang, 2006), which enables firms to avoid the pitfalls of using only guanxi, while also providing a critical tool for gaining new clients comparatively cheaply. Once retention has been achieved, customers are themselves encouraged to use their personal guanxi to attract new clients, who in turn are invited to do the same. The final hypothesized outcome of this model is therefore improved customer satisfaction and retention.

Effect of guanxi-type relationships on organizational relationships. Organizational trust and commitment are basic elements in relationship marketing, since the level of trust and commitment between exchange partners is a significant measure of the strength of the organizational relationship (Morgan \& Hunt, 1994). In our model, firms would harness their employees' personal networks (e.g., family, friends, locality, fictive kinship) to attract new customers, to be followed (after the initial transaction) by the deployment of traditional relationship marketing programs, to encourage repurchase behavior and link the consumer to the institution, generating organizational trust and commitment. Webster (1992) indicates that repeat transactions lead to relationship formation, while Palmatier, Jarvis, Bechkoff, and Kardes (2009: 13) find that relationship marketing programs significantly shape customers' feelings of gratitude, which in turn leads to stronger organizational relationships. Yen, Abosag, Huang, and Nguyen (2017) note that 
personal relationships can preserve existing organizational relationships as well as lubricating new ones. Interpersonal networks are therefore crucial in fostering effective organizational relationships (Berger et al., 2015). Based on these arguments, it is hypothesized that:

Hypothesis 1: Guanxi-type relationships have a significant positive effect on organizational relationships.

Effects of guanxi-type relationships and organizational relationships on guest satisfaction. Organizational relationships have been shown to be the most important variable in customer satisfaction, both in building (Berry, 1983) and increasing it (Smith \& Barclay, 1997), as well as in generating intention to remain (Morgan \& Hunt, 1994; Berry \& Parasuraman, 1991). Other studies agree that the level of organizational relationship influences both satisfaction and retention (Sin, Tse, Yau, Chow, Lee, \& Lau, 2005).

Berger et al. (2015) suggest that in an Arab context, satisfaction can be considered as an outcome of a guanxi-type relationship. Yen et al. (2017) note that human interaction, personal relationships, and friendship can sustain business relationships and lead to all the parties feeling satisfied. In a collectivist culture such as the Arab world, each of the guanxi-type relationship dimensions plays a significant role in building sustainable business relationships with a high level of satisfaction. Empathy along with personal trust, reciprocity, and face all play a key role of establishing business relationships and building satisfaction (Al-Omari, 2003, 2009; Barakat, 1993; Weir et al., 2019). The importance of empathy in maintaining business relationships and customer satisfaction in the Arab world is also underlined by the fact that the Middle Eastern communication model is receiver-centered, in contrast to the sender-centered Western model. In the Middle East, reciprocity also aids long-term relationships and satisfaction as it ensures a positive outcome, reduces uncertainty and ambiguity, and creates value (El-Said \& Harrigan, 2009; Mohamed \& Mohamad, 2011), as well as directly influencing business performance (Berger et al., 2015; Bian, 2018). Personal trust is another vital component to establish successful business relationships and ensure satisfaction afterwards, particularly in a culture where the word is the bond, what people shake hands on matters more than what they sign (Al-Omari, 2003, 2009; Hutchings \& Weir, 2006a; Weir et al., 2019). Moreover, in Middle Eastern culture, face plays a key role in relationships by emphasizing the notions of continuity, collaboration, and satisfaction (Berger et al., 2015). Affection also exists in the business relationship (Shou et al., 2011; Wang, 2007). It can be a sentiment-driven instrumental business tie with expectations of reciprocity and relationship retention (Bian, 2018; Butt, Shah, \& Sheikh, 2020). Elsharnouby and Parsons (2010: 1369) argued that emotions in business relationships lead to a 'moral obligation' of parties to give help and exchange favors which lead to satisfaction. Similarly, Al-Omari (2009) outlined the essential role that emotions play in the cohesion of people in Arabic culture and 
considered affection as one of the main reasons for establishing satisfaction in business relationships.

In summary, guanxi-type relationships and strong organizational relationships are seen as key variables leading to satisfaction, cooperative behaviors among parties, long-term relationships, and the success of relationship marketing (Morgan \& Hunt, 1994; Sin et al., 2005). We therefore propose:

Hypothesis 2: Guanxi-type relationships have a significant positive impact on guest satisfaction.

\section{Hypothesis 3: Organizational relationships have a significant positive impact on guest satisfaction.}

Effects of organizational relationships, guanxi-type relationships, and satisfaction on guest retention. Customer retention - the willingness to repurchase from the company in the future (Gupta \& Zeithaml, 2006) - has been described as a 'state of continuation of a business relationship with the firm' (Keiningham, Cooil, Aksoy, Andreassen, \& Weiner, 2007: 364). Driven by customer satisfaction, it shows the presence of a successful relationship between customer and organization (Farquhar, 2005; Reichheld, 1996), with many advantages (Bruhn, 2003; Zeithaml, Berry, \& Parasuraman, 1996), including greater purchasing frequency and the possibility of cross-selling. Satisfied customers may also be willing to pay a premium price to reduce alternative risk (Zeithaml et al., 1996), and might encourage friends and relatives to buy from the company, while not discouraging current clients (Boulding, Kalra, Staelin, \& Zeithaml, 1993). In addition, customer satisfaction has also been shown to result in more repeat purchases and lower switching rates (Al-Msallam, 2015), and to lead to increased customer loyalty, since satisfied customers are more likely to repurchase (Akbari, Nazarian, Foroudi, Amiri, \& Ezatabadipoor, 2020). Prior studies have focused more on retention and recovery than on attracting new business (Bruhn, 2003), since customer acquisition is considered to be between five and 10 times more costly than retention (Gummesson, 1999).

Building trust and commitment through organizational relationships is key to retention (Palmatier et al., 2009; Tang et al., 2008; Tseng, 2007), creating intent to stay in the relationship, and influencing the parties' long-term orientation (Abosag \& Naudé, 2014). In Arab culture, a combination of guanxi-type and organizational relationships could help to retain customers over the long term (Bejou, Ennew, \& Palmer, 1998; Little \& Marandi, 2003; Mittal \& Lassar, 1998), while in the Chinese context, the guanxi components of reciprocity and face may have a positive correlation with relationship longevity (Yen \& Barnes, 2011).

In Arab culture, retention can be considered as an outcome of a guanxi-type relationship and its dimensions. The closer the bond between the customers and the firm's representative, the more doubt is removed, and the more relationship retention is expected (Tsang, 1998). In addition, in the Middle East, empathy among business partners means they are expected to anticipate the exchange 
party's needs and feelings without being told; accordingly, this increases the willingness of all parties to maintain a long-term business relationship (Al-Omari, 2009; Wang, 2007; Weir et al., 2019; Yau et al., 2000). Moreover, continuous reciprocity aids long-term relationships as it enhances trust and reduces ambiguity (El-Said \& Harrigan, 2009; Mohamed \& Mohamad, 2011). In addition, personal trust in Arab culture precedes business and other transactions (Al-Omari, 2003, 2009; Hutchings \& Weir, 2006a). Accordingly, the level of interpersonal trust in the Middle East is of prime importance and supports initiating and retaining long-term relationships (Al-Omari, 2003, 2009; Barakat, 1993; Weir et al., 2019). Elsharnouby and Parsons (2010: 1370) argue that personal trust has a prominent role in business interactions as the Arab world is a risk-averse society. Hyder and Fregidou-Malama (2009: 266) indicate that personal trust is a cultural requirement and presenting in all deals to help maintain long-term relationships. In the Middle Eastern culture, face also plays a major role in maintaining network relationships (Chen, 2001; Shou et al., 2011), and has clear relevance for business as well as in social and moral spheres, emphasizing the notions of continuity and collaboration (Berger et al., 2015). Al-Omari (2009) and Barakat (1993) highlight Arab sensitivity to 'losing face' - a concept which is closely related to shame in the Arab world - which makes the Arab keen to keep long-term social and business relationships. Finally, affection is key to establishing lasting and firm business relationships (Shou et al., 2011; Wang, 2007). Al-Omari (2009) views emotions as being prevalent in relationships among people in the Arab world and even in a business context. Furthermore, affection can become a sentiment-driven instrumental tie with expectations of reciprocity and relationship retention (Bian, 2018; Butt et al., 2020).

This research explores whether customers introduced through guanxi-type relationships and then engaged in organizational relationships can be satisfied and retained in the long term; whether guanxi-type relationships influence customer retention or only client introduction; and whether organizational relationships and satisfaction eventually contribute to guest retention. We therefore propose:

Hypothesis 4: Guanxi-type relationships have a significant positive impact on guest retention.

Hypothesis 5: Organizational relationships have a significant positive impact on guest retention

Hypothesis 6: Guest satisfaction has a significant positive impact on guest retention guanxi.

\section{METHODS}

\section{Variables and Measures}

After defining the research variables, specifying the constructs, and drawing the boundaries, we generated a set of items to measure each variable, drawn from reliable measures of relevant constructs that had been published and validated in the

(C) The Author(s), 2021. Published by Cambridge University Press on behalf of The International Association for Chinese Management Research 
prior literature. Guanxi-type relationships were conceptualized as a second-order construct consisting of six first-order components (bonding, empathy, reciprocity, personal trust, face, and affection), which were each measured by four or five items (see Appendix I, Table I). We borrowed or adopted these items from Sin et al. (2005), Lee and Dawes (2005), Mavondo and Rodrigo (2001), Smith and Barclay (1999), and Yen and Barnes (2011). Organizational relationships were operationalized using eight items from Sin et al. (2005) and Ndubisi (2007); while the consequences of guanxi-type relationships (customer satisfaction and retention) were measured using items from Eid (2015), Eid and El-Gohary (2015), Lee and Jun (2007), and Trasorras, Weinstein, and Abratt (2009). These trusted measures formed the basis of a questionnaire that was designed and tested in line with the advice of previous scholars (Anderson \& Gerbing, 1988; Churchill, 1979; Eid, 2009; Netemeyer, Bearden, \& Sharma, 2003). We piloted the survey with 20 hotel guests to refine the wording and make it more relevant to practices in the Middle East; this was then undertaken with a group similar to the final target population (Salaheldin \& Eid, 2007; Saunders, Lewis, \& Thornhill, 2012). The pre-testing exercise resulted in only minor changes to the existing scales, e.g., to clarify the wording.

To avoid the risk of common method bias (Podsakoff, MacKenzie, Lee, \& Podsakoff, 2003), we carefully designed the questionnaire to minimize its occurrence, and assessed its potential presence in the data in two ways (Podsakoff \& Organ, 1986), which confirmed it was not a serious concern. Harman's single-variable test showed that the largest factor accounted for $30.18 \%$ (variances ranged from $17.56 \%$ to $23.41 \%$ ), and no single factor accounted for more than $50 \%$ of the variance; while Lindell and Whitney's (2001) marker variable method showed that all coefficients remained significant after the marker variable had been controlled.

\section{Context of Data Collection and Sampling}

The hotel industry is the context of the data collection for this study. The global tourism and hospitality industry has expanded considerably in the past few years, leading to recognition of its importance to the development agenda, given that it is already transforming entire communities as well as individual lives (UNWTO International Tourism Highlights, 2019). By 2019, global export earnings from tourism stood at US \$1.7 trillion (UNWTO), while the global hotel industry had an estimated retail value of US $\$ 600.49$ billion in 2018 (Statista, 2020). These rising figures have been matched by an expansion in jobs and in the nature of the services provided, including the growing popularity of tourism that reflects the cultural heritage of host communities (Akbari et al., 2020).

Despite these significant gains, the hospitality industry as a whole, and the hotel sector within it, remain at the mercy of internal and external factors (Farrington, Gurran, Gori, Gorman, \& Queenan, 2017) such as political events, 
economic downturns, social unrest, and fluctuating year-on-year or seasonal demand. The use of guanxi-type relationships is increasingly recognized by both practitioners and academics as an important source of stability in changing external circumstances. In support, Zhang et al. (2020) argue that interpersonal relationships (e.g., guanxi-type relationships) are playing a crucial role in the tourism and hospitality sector. However, deeper insights are still needed, especially in the service context of the hotel industry (Akbari et al., 2020; Mohammed \& Rashid, 2018). Furthermore, focusing on market-specific traits of the target market is key to ensuring positive brand outcomes and gaining customer support (Akbari et al., 2020), emphasizing the importance of fully understanding the cultural and social factors of a market such as the Middle East, which could benefit significantly from the economic and development potential of the ongoing expansion of its tourism and hospitality sector.

We conducted the main data collection from January to May 2017, using purposive sampling. The unique target population was hotel guests in the Middle East who had been introduced by a member of staff or another guest with whom they had a personal relationship (guanxi). Since our aim was to analyze the effects of guanxi-type relationships and organizational relationships on guest retention in the Middle East, 17 countries across the region were selected, and 300 suitable hotels were identified in capitals or other major cities, located in areas that represented important destinations for guests. We distributed 1,200 questionnaires evenly between the hotels, of which 651 were completed and returned. Fourteen were eliminated owing to incomplete answers, leaving a total of 637 useable questionnaires (an overall response rate of 53.08\%). These responses were spread across the 17 countries in the following proportions: Bahrain 2.4\%, Egypt 13.3\%, Iran $2.3 \%$, Iraq 2.6\%, Jordan 5.1\%, Kuwait 3.2\%, Lebanon 10.3\%, Libya 3.1\%, Oman 3.2\%, Palestine 3.1\%, Qatar 4.5\%, Saudi Arabia 9.6\%, Sudan 2.8\%, Syria $3.1 \%$, Turkey $12.3 \%$, UAE $17.3 \%$, and Yemen $1.8 \%$. The demographics of the respondents are shown in Table 1.

\section{RESULTS}

Following Anderson and Gerbing's (1988) recommendation, we used a two-step approach separating the measurement model from the structural model. We assessed the psychometric properties (discriminant validity, convergent validity, and reliability) of the measures used before using structural equation modelling to examine the hypothesized relationships.

\section{Reliability and Validity of the Measures}

First, we calculated Cronbach's alpha reliability coefficient and items-to-total correlation. This analysis led to the deletion of two items from the guanxi-type relationships construct and one from the organizational relationships construct. All the 
Table 1. Analysis of the descriptive statistics of the sample

Characteristics

Age

Income Level

Education

Table 2. Reliability analysis

Gender
Percentage

$\begin{array}{lr}\text { Less than } 20 \text { Years } & 23.5 \\ \text { 20-30 Years } & 41.9 \\ \text { 31-40 Years } & 20.4 \\ \text { 41-50 Years } & 4.1 \\ \text { More than 50 Years } & 10.1 \\ \text { Less than 1000 USD } & 22.2 \\ \text { 1000-1999 USD } & 56.8 \\ \text { 2000-2999 USD } & 14.4 \\ \text { 3000-4999 USD } & 4.3 \\ \text { More than 5000 USD } & 2.3 \\ \text { Intermediate } & 1.1 \\ \text { Secondary } & 53.5 \\ \text { Diploma } & 34.2 \\ \text { Bachelor } & 9.4 \\ \text { Postgraduate } & 1.7 \\ \text { Male } & 69.2 \\ \text { Female } & 30.8\end{array}$

Less than 20 Years

23.5

20.4

4.1

22.2

56.8

2.3

Female

\begin{tabular}{lcccc}
\hline Constructs & No. of items & Mean & SD & Reliability \% \\
\hline Guanxi-Type Relationship (GTR) & 6 & 3.79 & 0.71 & $\mathbf{9 3 . 2}$ \\
Organizational Relationships (OR) & 8 & 3.86 & 0.67 & $\mathbf{8 9 . 6}$ \\
Guest Satisfaction (GS) & 4 & 3.80 & 0.84 & $\mathbf{8 4 . 1}$ \\
Guest Retention (GR) & 5 & 3.72 & 0.69 & $\mathbf{8 5 . 3}$ \\
\hline \hline
\end{tabular}

scales had reliability coefficients ranging from 0.84 to 0.93 , which all exceeded the cut-off level of 0.65 set for basic research (Bagozzi, 1994: 96), as shown in Table 2.

We then conducted exploratory factor analysis (see Appendix I, Table I) using all the items (with varimax rotation) to check the unidimensionality of the underlying factor structure. Elements which did not have dominant loadings greater than 0.50 or cross-loadings less than 0.50 were deleted (Hair, Black, Babin, Ralph, \& Ronald, 2006). Using an eigenvalue of 1.0 as the cut-off point, four constructs were extracted (explaining more than $74.51 \%$ of the extracted variance).

\section{Measurement Model Testing}

To achieve strong convergent and discriminant validity, we used confirmatory factor analysis to examine the four measures. Convergent validity explains how the items of a certain variable congregate or share a high percentage of variance (Hair et al., 2006). As the average variance extracted (AVE) for all the measures 
Table 3. Measurement model results: Confirmatory factor analysis

\begin{tabular}{|c|c|c|c|c|}
\hline & \multicolumn{4}{|c|}{ Correlations } \\
\hline & GTR & $O R$ & $G S$ & $G R$ \\
\hline Guanxi-Type Relationships (GTR) & 0.85 & & & \\
\hline Organizational Relationships (OR) & $0.16^{* * *}$ & 0.87 & & \\
\hline Guest Satisfaction (GS) & $0.11^{* *}$ & $0.09 * *$ & 0.75 & \\
\hline Guest Retention (GR) & $0.13^{* * *}$ & $0.07 * *$ & $0.14^{* * * *}$ & 0.73 \\
\hline Coefficient Alpha & 0.93 & 0.89 & 0.84 & 0.85 \\
\hline
\end{tabular}

Notes: The diagonals represent the average variance extracted and the lower cells represents the squared correlation among constructs. $* * P<0.05 ; * * * P<0.01$

was more than 0.50, convergent validity was met. The results, presented in Table 3, show that the AVE values were higher than any squared correlation among the variables, hence indicating good discriminant validity of the constructs and the measures were practically different (Fornell \& Larcker, 1981).

\section{Structural Model Testing}

After confirming the relevance of the measurement model, we developed and tested a structural model. We used factor scores to represent single item indicators for each construct in the model, and performed path analysis using the maximum likelihood estimates (MLE) method (Jöreskog \& Sorbom, 1982). The results and measures for model fit are shown in Table 4.

Before testing the hypotheses, we used different non-normal distributions tests to check the normality of the constructs (Bagozzi \& Yi, 1988). Skewness, kurtosis, and the Mahalanobis distance statistics of the final measures were checked (Bagozzi $\&$ Yi, 1988). No deviation from normality was found for any measure. All the constructs were normally distributed, with deviation well within acceptable ranges. We then progressed to using the MLE method to establish the model. Figure 2 illustrates the path diagram for the causal model.

Since there is no definitive standard of fit, we used different indicators. The Chi-square test was not statistically significant, which indicated a good fit. The other fit indicators, along with the squared multiple correlations, reflected a good overall fit with the data $(\mathrm{GFI}=0.95, \mathrm{AGFI}=0.88, \mathrm{CFI}=0.96, \mathrm{NFI}=0.96$, RMSEA = 0.04). As these indicators were acceptable, we decided the structural model was an appropriate tool for hypothesis testing.

\section{RESULTS}

The conceptual model and hypotheses were supported by the findings. The estimated standardized parameters for the causal relationships are shown in Table 4. Firstly, guanxi-type relationships were found to have a significant impact

(C) The Author(s), 2021. Published by Cambridge University Press on behalf of The International Association for Chinese Management Research 
Table 4. Standardized regression weights

\begin{tabular}{|c|c|c|c|c|c|}
\hline Predictor Variables & Criterion Variables & Hypothesized Relationship & Standardized Coefficient & P-Value & $R^{2 a}$ \\
\hline Guanxi-Type Relationships & Organizational Relationships & H1 & $0.54 * * *$ & 0.000 & 0.29 \\
\hline Guanxi-Type Relationships & Guest Satisfaction & H2 & $0.39 * * *$ & 0.000 & 0.52 \\
\hline Org-Relationships & Guest Satisfaction & H3 & $0.43 * * *$ & 0.000 & \\
\hline Guanxi-Type Relationships & Guest Retention & H4 & $0.38 * * *$ & 0.000 & 0.87 \\
\hline Org-Relationships & Guest Retention & H5 & $0.35 * * *$ & 0.000 & \\
\hline Guest Satisfaction & Guest Retention & H6 & $0.36 * * *$ & 0.000 & \\
\hline Statistic & & & & Suggested & Obtained \\
\hline Chi-Square Significance & & & & $\geq 0.05$ & 0.26 \\
\hline GFI & & & & $\geq 0.90$ & 0.95 \\
\hline AGFI & & & & $\geq 0.80$ & 0.88 \\
\hline CFI & & & & $\geq 0.90$ & 0.96 \\
\hline RMSEA & & & & $\leq 0.08$ & 0.04 \\
\hline
\end{tabular}




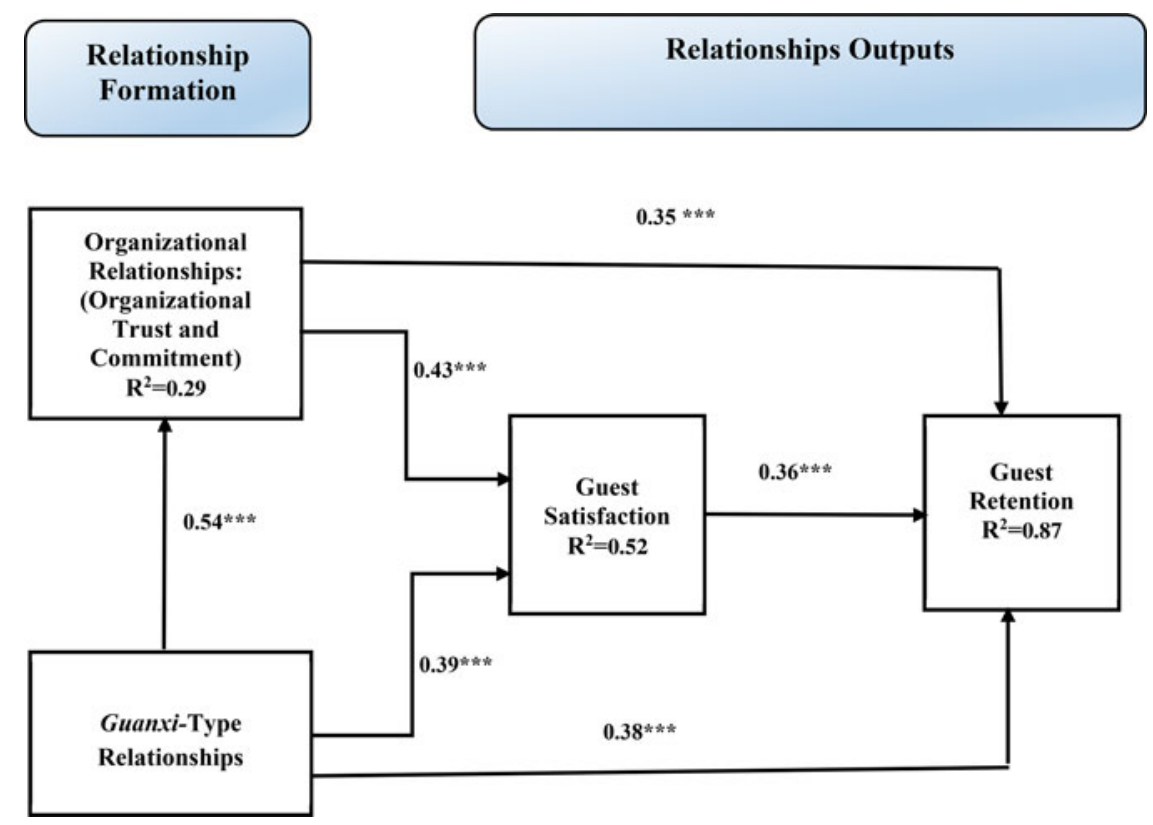

Figure 2. The tested model

on the formation of organizational relationships (Hypothesis 1) (standardized estimate $=\mathbf{0 . 5 4}, \mathrm{P}<0.001)$. Therefore, Hypotheses 1 was accepted. Secondly, both guanxi-type relationships (Hypothesis 2) (standardized estimate $=\mathbf{0 . 3 9}$, $\mathrm{P}<0.001$ ) and organizational relationships (Hypothesis 3) (standardized estimate $=\mathbf{0 . 4 3}, \mathrm{P}<0.001$ ) were found to significantly affect guest satisfaction. Therefore, Hypotheses 2 and 3 were accepted. Finally, the suggested factors were found to positively affect guest retention as follows: guanxi-type relationships $($ Hypothesis 4) (standardized estimate $=\mathbf{0 . 3 8}, \mathrm{P}<0.001$ ), organizational relationships (Hypothesis 5) (standardized estimate $=\mathbf{0 . 3 5}, \mathrm{P}<0.001$ ), and guest satisfaction (Hypothesis 6) (standardized estimate $=\mathbf{0 . 3 6}, \mathrm{P}<0.001$ ). Therefore, Hypotheses 4, 5, and 6 were accepted. The empirical analysis shows that most of the hypothesized relationships are, as expected, significant. The three suggested variables (guanxi-type relationships, organizational relationships, and guest satisfaction) jointly explain $87 \%$ of the variance in guest retention.

Because the causal effects of guanxi-type relationships and organizational relationships on guest retention can be either direct or indirect, i.e., they are mediated via the effect of guest satisfaction, we calculated the indirect causal effects and their total. Table 5 shows the direct, indirect, and total effects of the suggested factors.

\section{DISGUSSION}

Our results shed light on a number of aspects of guanxi-type relationships in the Middle East, including their implications for organizational relationships and customer retention. These are discussed in detail in the following sections.

(C) The Author(s), 2021. Published by Cambridge University Press on behalf of The International Association for Chinese Management Research 
Table 5. Direct, indirect, and total effect of CRM usage

\begin{tabular}{llccc} 
Criterion Variable & \multicolumn{1}{c}{ Predictor Variables } & Direct Effect & Indirect Effect & Total Effect \\
\hline Organizational Relationship & Guanxi-Type Relationships & 0.54 & 0.00 & 0.54 \\
Guest Satisfaction & Guanxi-Type Relationships & 0.39 & 0.23 & 0.62 \\
& Organizational Relationship & 0.43 & 0.00 & 0.43 \\
Guest Retention & Guanxi-Type Relationships & 0.38 & 0.41 & 0.79 \\
& Organizational Relationship & 0.35 & 0.15 & 0.50 \\
& Guest Satisfaction & 0.36 & 0.00 & 0.36 \\
\hline \hline
\end{tabular}

\section{Guanxi-Type Relationships}

We have demonstrated that the dimensions of guanxi-type relationships introduced in the Chinese context can contribute to the formation of such relationships in the Middle East. All the related hypotheses were supported. The associations we have shown between guanxi-type relationships, organizational relationships, guest satisfaction, and retention offer valuable new insights for the hospitality industry in the Middle East, which currently uses only relationship marketing to build organizational relationships with customers (Flambard-Ruaud, 2005; Geddie et al., 2005). Organizational relationship could become a natural progression from guanxi-type relationships (Geddie et al., 2005). By examining the factors influencing guanxi-type relationships in the Middle East, and the outcomes of these relationships in a hospitality context, we have also demonstrated how each proposed dimension of guanxi presents a chance to use a strategy based on these relationships, with the general aim of improving both guest satisfaction and retention.

\section{Organizational Relationships}

Our findings that guanxi-type relationships have a direct and significant influence on organizational relationships are in agreement with those of Nicholson, Compeau, and Sethi (2001). Notably, this link had the highest coefficient in our model (0.54), supporting our theoretical view of the crucial role played by personal relationships in the development of organizational relationships. This finding shows that interpersonal relationships are a key antecedent of organizational relationships in the Middle East. In other words, without guanxi-type relationships, organizational relationships might not develop.

\section{Guest Satisfaction}

Our results support previous findings that organizational relationships are central to customer satisfaction and retention. For example, Anosike and Eid (2011) and Sin et al. (2002) found that an increase in trust between customer and supplier raised the likelihood of building satisfaction and a long-term relationship. 
Furthermore, our findings, which were obtained in Middle Eastern collectivist cultures, support a number of previous theoretical views. For instance, Abosag and Naudé (2014) argued that this special type of relationship (guanxi) had a greater chance of achieving customer satisfaction than normal, less culturally dependent types of relationships.

\section{Guest Retention}

Guanxi-type relationships, organizational relationships, and guest satisfaction were collectively found to explain $87 \%$ of guest retention. The highest coefficient in the model (0.38) was the association between guanxi-type relationships and retention. We have therefore shown that establishing better interpersonal relationships allows hotels to interact with, respond to, and communicate more effectively with guests, leading to a significant improvement in retention rates. Converting these interpersonal ties into the type of organizational relationship central to relationship marketing (Zhang \& Zhang, 2006) increases customer satisfaction and customer retention (Tang et al., 2008; Tseng, 2007). Relationship marketing programs can therefore be supplemented in the Middle Eastern context by adding the use of guanxi-type relationships. This also renders the programs more adaptable to nonWestern cultural characteristics and problems (e.g., lack of trust) (Flambard-Ruaud, 2005). The catalytic effect of guest satisfaction on retention was also clearly shown.

We were initially surprised to find that guanxi-type relationships had a similar effect to organizational relationships and guest satisfaction on retention. However, we realized this was predictable, since the direct effect is enhanced by the indirect positive effect (0.41); it is not just the guanxi-type relationships themselves that lead to positive perceptions and retention, but also the hotels' efforts to build on them by developing organizational relationships.

\section{Managerial Contributions}

We have clearly shown the importance of integrating guanxi into business practices, given its potential to improve customer recruitment, satisfaction, and retention, thereby delivering significant advances for the company. It also enhances managers' understanding of the different variables that make up guanxi-type relationships, enabling them to deploy better positioning strategies. On the basis of our results, Middle Eastern hotels should consider applying guanxi-type relationships and converting them into organizational relationships (Zhang \& Zhang, 2006), thus improving guest satisfaction and retention (Tang et al., 2008; Tseng, 2007). In this hybrid strategy, hotels would use employees' interpersonal relationships to attract new guests as a precursor to the building organizational ties through relationship marketing. The many benefits of this strategy include building long-term relationships, avoiding the risks of strategies based only on guanxi-type relationships (Arias, 1998), and attracting new customers at little cost (Dunfee \& Warren, 2001). 
Our findings also enhance manager understanding of the interplay between organizational relationships, guest satisfaction, and guest retention, offering significant advantages to hotels (Zeithaml \& Bitner, 1996). Eid and El-Gohary (2015) note that retained customers promote the company among their relatives and friends. Such positive word-of-mouth communication has a significant indirect effect on company returns. In support, Al-Msallam (2015), states that customer satisfaction leads to lower switching rates, and more repeat purchases. Similarly, satisfaction is seen as a prerequisite to developing customer loyalty, with satisfied customers showing more loyalty in their purchase decisions (Akbari et al., 2020). Finally, our results show managers the importance of training employees so they build trusting relationships with guests and show empathy when handling their problems, as this strengthens organizational relationships. This should also help increase guest bonding with the hotel (Geddie et al., 2005).

\section{Theoretical Contributions}

Our study makes a number of theoretical contributions. Firstly, it introduces a novel, unified model integrating guanxi into the existing relationship marketing framework. This shows the potential for using interpersonal relationships to attract customers and organizational relationships to retain them. This theoretically derived model has implications for the recruitment, satisfaction, and retention of customers, as well as offering valuable insights into cultural factors. Our study therefore contributes significantly to both the guanxi and relationship marketing literature by linking the two strands and creating a new concept. While some prior studies had inferred an association between social networks and relationship marketing (Geddie et al., 2002, 2005; Shaalan et al., 2013), none had sought to link them, and no unified model previously existed. Furthermore, we have tested this model quantitatively and provided evidence of its applicability and effectiveness in the hotel sector in the Middle East. By introducing a means of converting guanxi-type ties into the organizational links involved in relationship marketing, we have also demonstrated a new route to increased customer satisfaction and retention.

Furthermore, we clearly show the outcomes of integrating guanxi-type relationships into marketing strategies in the Middle East. Our results can be considered unique, since this is the first study to deal with this problem and the unique unit of analysis, namely hotel guests in the Middle East who had been introduced by an employee or another guest with whom they had a personal relationship. Previous studies on relationship marketing, which considered the customer as the unit of analysis, dealt only with the business customer or final consumer. In addition to providing the first empirical evidence that a company can attract customers using guanxi and retain them using marketing strategies, we validate previous research on the impact of relationship marketing on customer retention, by testing relationship marketing and social network theories in a new geographical 
area (the Middle East), with a different unit of analysis and a unique problem. We therefore extend both the guanxi and relationship marketing literature by providing much-needed empirical support for the use and influence of guanxi-type relationships into the framework of relationship marketing in the Middle East.

Finally, we contribute to the literature by providing empirical evidence from the Middle East - an under-researched region in terms of business-to-customer relationships - on the role of guanxi-type relationships and organizational relationships in enhancing customer satisfaction and retention.

\section{Limitations and Future Research Directions}

As with any research, there are some limitations. Since this study was conducted exclusively in the Middle East, its outputs should be interpreted with care outside collectivist cultures or those with guanxi-type relationships, and cannot be considered as generalizable to Western cultures without further exploration. More research is therefore needed on all aspects of relationships based on social networks in different regions. The applicability and effectiveness of our research model should be tested in these settings. A comparative study applying the model in different cultures, including Asia and the West, would also enhance understanding of the nature of social networks in varying settings. There is also a need for both more qualitative and quantitative studies on all aspects of social networks in Western, Arab, and Asian cultures.

Since our research targeted only hotel guests, future studies using the model in different Middle Eastern sectors would strengthen generalizability, and comparing these results with our findings would also enrich the literature. Another potential limitation comes from the quantitative, customer-centered design of the empirical study. Future research could explore managers' and employees' perspectives, or follow a qualitative design to explore the constructs in greater depth, as well as testing the applicability of the concepts and the model in business-to-business contexts. Finally, our cross-sectional sampling approach means the potential causal impacts between the constructs can be inferred from the underlying theory rather than from the data itself (Rudestam \& Newton, 2007); a longitudinal research design would help confirm the potential causal relationships in our study. We hope our findings augment the literature and provide a reference point from which subsequent research can evolve.

\section{GONGLUSION}

Our study has investigated guanxi holistically and has expanded understanding of its dimensions beyond China, specifically in the Middle East, while also highlighting its differences with Western networks. We have explored the effects of incorporating guanxi-type relationships into existing relationship marketing frameworks in Middle Eastern countries; how these relationships affect guest satisfaction and 
retention; and how they can be successfully transformed into organizational relationships. All six of our hypotheses were supported.

Our main contribution is the introduction of a model blending guanxi-type relationships with relationship marketing. Overall, our findings indicate that: (a) guanxi-type relationships in the Middle Eastern have six dimensions - bonding, empathy, reciprocity, personal trust, face, and affection; (b) guanxi-type relationships, and organizational relationships are antecedents of Middle Eastern guests' satisfaction; and (c) guanxi-type relationships, organizational relationships, and guest satisfaction have positive impacts on intention to return.

\section{APPENDIX I}

\section{Scale Items, Factor Loadings, and Sources}

\begin{tabular}{|c|c|c|}
\hline Construct/Items & $\begin{array}{l}\text { Factor } \\
\text { Loading }\end{array}$ & Source \\
\hline \multicolumn{3}{|c|}{ Bonding (B): [variance extracted: $6.07 \%] 3$} \\
\hline Rely on each other & 0.69 & \multirow{5}{*}{$\begin{array}{l}\text { Adopted from Sin, Tse, Yau, Lee, and } \\
\text { Chow (2005), and Mavondo and } \\
\text { Rodrigo (2001) }\end{array}$} \\
\hline Interact on a social basis & 0.76 & \\
\hline $\begin{array}{l}\text { Do our best to set up a long-term } \\
\text { relationship }\end{array}$ & 0.79 & \\
\hline Keep in touch constantly & 0.81 & \\
\hline Talk openly as friends & 0.59 & \\
\hline \multicolumn{3}{|c|}{ Empathy (E): [variance extracted: $3.87 \%] 7$} \\
\hline Understand each other's viewpoint & 0.63 & \multirow{4}{*}{$\begin{array}{l}\text { Adopted from Sin, Tse, Yau, Lee, and } \\
\text { Chow (2005) }\end{array}$} \\
\hline Understand each other's needs & 0.68 & \\
\hline $\begin{array}{l}\text { Show sympathy when the other has } \\
\text { problems }\end{array}$ & 0.78 & \\
\hline $\begin{array}{l}\text { Provide support when the other has } \\
\text { problems }\end{array}$ & 0.78 & \\
\hline \multicolumn{3}{|c|}{ Reciprocity (R): [variance extracted: $5.42 \%] 4$} \\
\hline $\begin{array}{l}\text { The practice of give and take of favors is a } \\
\text { key part }\end{array}$ & 0.81 & \multirow[t]{4}{*}{$\begin{array}{l}\text { Adopted from Mavondo and Rodrigo } \\
\text { (2001), Yen and Barnes (2011). }\end{array}$} \\
\hline $\begin{array}{l}\text { Calling in favors is part of social } \\
\text { interaction }\end{array}$ & 0.83 & \\
\hline $\begin{array}{l}\text { Favors we do for each other have built } \\
\text { good relationships }\end{array}$ & 0.82 & \\
\hline $\begin{array}{l}\text { We feel a sense of obligation for receiving } \\
\text { favors from each other }\end{array}$ & 0.80 & \\
\hline \multicolumn{3}{|c|}{ Personal Trust (PT): [variance extracted: $30.00 \%] 1$} \\
\hline Is trustworthy & 0.80 & \multirow{6}{*}{$\begin{array}{l}\text { Adopted from Smith and Barclay (1999), } \\
\text { Lee and Dawes (2005) }\end{array}$} \\
\hline Is very honest & 0.77 & \\
\hline Is dependable & 0.76 & \\
\hline Fulfils his/her promises & 0.81 & \\
\hline Does not make any false claims & 0.76 & \\
\hline Face $(\mathbf{F}):$ [variance extracted: $2.59 \%$ ] & & \\
\hline
\end{tabular}

(C) The Author(s), 2021. Published by Cambridge University Press on behalf of The International Association for Chinese Management Research 
Continued

\begin{tabular}{|c|c|c|}
\hline Construct/Items & $\begin{array}{l}\text { Factor } \\
\text { Loading }\end{array}$ & Source \\
\hline Care about how others see us & 0.78 & Adopted from Lee and Dawes (2005) \\
\hline $\begin{array}{l}\text { Believe the more respect we receive, the } \\
\text { more 'face' we have }\end{array}$ & 0.80 & \\
\hline $\begin{array}{l}\text { Feel a 'loss of face' when others turn down } \\
\text { our favors }\end{array}$ & 0.78 & \\
\hline $\begin{array}{l}\text { Take care not to make each other feel } \\
\text { uncomfortable in any situation }\end{array}$ & 0.69 & \\
\hline \multicolumn{3}{|c|}{ Affection (A): [variance extracted: $4.41 \%] 6$} \\
\hline Like each other & 0.59 & Adopted from Lee and Dawes (2005) \\
\hline $\begin{array}{l}\text { Enjoy meeting each other in a relaxed } \\
\text { environment (e.g., dining out) }\end{array}$ & 0.74 & \\
\hline $\begin{array}{l}\text { Present souvenirs to each other (they need } \\
\text { not be expensive) }\end{array}$ & 0.65 & \\
\hline Enjoy communication with each other & 0.79 & \\
\hline Enjoy helping each other & 0.68 & \\
\hline
\end{tabular}

Organizational Relationships(OR): [variance extracted: $9.09 \%$ ] 2

Can be trusted $\quad 0.81$

Treats me honestly

Provides reliable promises

Is consistent in providing quality products or/and services

Carries out what the contact person promises

I would still keep buying from the hotel, even if this would be more difficult

I can make sacrifices to help this hotel (e.g., money, effort, time, etc)

I will continue to deal with this hotel even if its prices increase in the future

\section{Guest Satisfaction (GS): [variance} extracted: $3.09 \%] \mathrm{B}$

My decision to book this hotel was a good decision

I did the right thing when I booked this hotel

This experience is precisely what I looked for

I am happy about my decision to book the selected hotel

\section{Guest Retention (GR): [variance extracted: $4.58 \%] 5$}

I have an intention to repurchase from this hotel in future

I will continue to purchase from this hotel I recommend this hotel to all my social network (friends, colleagues, and relatives)

I expect my relationship with this hotel to last a long time

I usually pay less attention to competitors' offers
0.81
0.82

0.76

0.68
Adopted from Sin, Tse, Yau, Lee, and Chow (2005), and Ndubisi (2007)

Adopted from Eid (2015), and Eid and ElGohary (2015)

Adopted from Lee and Jun (2007), and Trasorras, Weinstein, and Abratt (2009)

(C) The Author(s), 2021. Published by Cambridge University Press on behalf of The International Association for Chinese Management Research 


\section{REFERENGES}

Abosag, I., \& Naudé, P. 2014. Development of special forms of B2B relationships: Examining the role of interpersonal liking in developing guanxi and et-moone relationships. Industrial Marketing Management, 43(6): 887-896.

Akbari, M., Nazarian, A., Foroudi, P., Amiri, N., \& Ezatabadipoor, E. 2020. How corporate social responsibility contributes to strengthening brand loyalty, hotel positioning and intention to revisit? Current Issues in Tourism: 1-21.

Al-Msallam, S. 2015. Customer satisfaction and brand loyalty in the hotel industry. International Joumal of Management Sciences and Business Research, 4: 232-251.

Al-Omari, J. 2003. The Arab way: How to work more effectively with Arab cultures. Oxford: How To Books.

Al-Omari, J. 2009. Understanding the Arab culture: A practical cross-cultural guide to working in the Arab zeorld. Oxford: How To Books.

ALHussan, F. B., Al-Husan, F. B., \& Alhesan, L. 2017. The role of senior executives in managing key customers in Arab context. Journal of Business \& Industrial Marketing, 32(6): 825-835.

ALHussan, F. B., AL-Husan, F. B., \& Chavi, C. Y. 2014. Environmental factors influencing the management of key accounts in an Arab Middle Eastern context. Industrial Marketing Management, 43(4): 592-602.

Alston, J. P. 1989. Wa, guanxi, and inhwa: Managerial principles in Japan, China, and Korea. Business Horizons, 32(2): 26-31.

Anderson, J. C., \& Gerbing, D. W. 1988. Structural equation modelling in practice: A review and recommended two-step approach. Psychological Bulletin, 103(3): 411-423.

Ang, S. H., \& Leong, S. M. 2000. Out of the mouths of babes: Business ethics and youths in Asia. Journal of Business Ethics, 28(2): 129-144.

Anosike, U. P., \& Eid, R. 2011. Integrating internal customer orientation, internal service quality and customer orientation in the banking sector: An empirical study. Service Industries Journal, 31(14): 2487-2505.

Arias, J. T. G. 1998. A relationship marketing approach to guanxi. European Journal of Marketing, 32(1-2): 145-156.

Bagozzi, R. P. 1994. Measurement in marketing research: Basic principles of questionnaire design. Principles of Marketing Research, (1): 1-49.

Bagozzi, R. P., \& Yi, Y. 1988. On the evaluation of structural equation models. Journal of the Academy of Marketing Science, 16(1): 74-94.

Barakat, H. 1993. The Arab zorld: Society, culture, and state. Berkeley: University of California Press.

Barnes, B. R., Yen, D., \& Zhou, L. 2011. Investigating guanxi dimensions and relationship outcomes: Insights from Sino-Anglo business relationships. Industrial Marketing Management, 40(4): $510-521$.

Barnes, B. R., Leonidou, L. C., Siu, N. Y. M., \& Leonidou, C. N. 2015. Interpersonal factors as drivers of quality and performance in Western-Hong Kong interorganizational business relationships. Journal of International Marketing, 23(1): 23-49

Barnett, A., Yandle, B., \& Naufal, G. 2013. Regulation, trust, and cronyism in Middle Eastern societies: The simple economics of wasta. Joumal of Socio-Economics, 44: 41-46.

Bejou, D., Ennew, C. T., \& Palmer, A. 1998. Trust, ethics and relationship satisfaction. International Journal of Bank Marketing, 16(4): 170-175.

Berger, R., \& Herstein, R. 2012. The limits of guanxi from the perspective of the Israeli Diamond Industry. Journal of Chinese Economic and Foreign Trade Studies, 5(1): 29-41.

Berger, R., Herstein, R., McCarthy, D., \& Puffer, S. 2019. Doing favors in the Arab world. International Journal of Emerging Markets, 14(5): 916-943.

Berger, R., Silbiger, A., Herstein, R., \& Barnes, B. R. 2015. Analyzing business-to-business relationships in an Arab context. Journal of World Business, 50(3): 454-464.

Berry, L. L. 1983. Relationship marketing. In L. L. Berry, G. L. Shostack, \& G. D. Upah (Eds.), Emerging perspectives on services marketing: 8-25. Chicago: American Marketing Association.

Berry, L. L. 2002. Relationship marketing of services: Perspectives from 1983 and 2000.Journal of Relationship Marketing, 1(1): 59-94.

Berry L. L., \& Parasuraman, A. 1991. Marketing services: Competing through quality. New York: The Free Press. 
Bian, Y. 1994. Guanxi and the allocation of urban jobs in China. The China Quarterly, 140(1): 971-999.

Bian, Y. 1997. Bringing strong ties back in: Indirect ties, network bridges, and job searches in China. American Sociological Revieze, 62(3): 366-385.

Bian, Y. 2006. Guanxi. In J. Beckert \& M. Zafirovski (Eds.), International encyclopaedia of economic sociology. New York: Routledge.

Bian, Y. 2018. The prevalence and the increasing significance of guanxi. The China Quarterly, 235 (3): 597-621.

Bian, Y., \& Ang, S. 1997. Guanxi networks and job mobility in China and Singapore. Social Forces, 75(3): 981-1005.

Bian, Y., \& Ikeda, K. 2014. East Asian social networks. In R. Alhajj \& J. Rokne (Eds.), The encyclopaedia of social network analysis and mining: 417-433. New York: Springer.

Björkman, I., \& Kock, S. 1995. social relationships and business networks: The case of Western companies in China. International Business Revieze, 4(4): 519-535.

Boulding, W., Kalra, A., Staelin, R., \& Zeithaml, V. A. 1993. A dynamic process model of service quality: From expectations to behavioral intentions. Journal of Marketing Research, 30(1): 7-27.

Bruhn, M. 2003. Relationship marketing: Management of customer relationships. Harlow: Financial Times/Prentice-Hall.

Burt, R. S. 2019. Network disadvantaged entrepreneurs: Density, hierarchy, and success in China and the West. Entrepreneurship Theory and Practice, 43(1): 19-50.

Burt, R. S., \& Burzynska, K. 2017. Chinese entrepreneurs, social networks, and guanxi. Management and Organization Revieze, 13(2): 221-260.

Burt, R. S., \& Opper, S. 2017. Early network events in the later success of Chinese entrepreneurs. Management and Organization Revieze, 13(3): 497-537.

Burt, R. S., Bian, Y., \& Opper, S. 2018. More or less guanxi: Trust is 60\% network context, 10\% individual difference. Social Networks, 54: 12-25.

Butt, A. S., Shah, S. H. H., \& Sheikh, A. Z. 2020. Is guanxi important in a buyer-supplier relationship? Case of Chinese logistics industry. Journal of Asia Business Studies, 14(1): 1-14.

Cao, Q., Baker, J., \& Schniederjans, D. 2014. Bullwhip effect reduction and improved business performance through guanxi: An empirical study. International Journal of Production Economics, 158: 217-230.

Chambers, D., \& Buzinde, C. 2015. Tourism and decolonisation: Locating research and self. Annals of Tourism Research, 51: 1-16.

Chen, M. 2001. Inside Chinese business: A guide for managers worldwide. Boston: Harvard Business School Press.

Chen, M. H., Chang, Y. Y., \& Lee, C. Y. 2015. Creative entrepreneurs' guanxi networks and success: Information and resource. Journal of Business Research, 68(4): 900-905.

Chen, X. 2017. A phenomenological explication of guanxi in rural tourism management: A case study of a village in China. Tourism Management, 63: 383-394.

Chen, X., \& Chen, C. 2004. On the intricacies of the Chinese guanxi: A process model of guanxi development. Asia Pacific Joumal of Management, 21(3): 305-324.

Chung, H. F. 2019. How guanxi networking matters in the relation between market orientation and innovation in Asian emerging economies - the case of Markor. Journal of Business \& Industrial Marketing, 34(4): 836-849.

Chung, H. F., Yang, Z., \& Huang, P. H. 2015. How does organizational learning matter in strategic business performance? The contingency role of guanxi networking. Journal of Business Research, 68(6): 1216-1224.

Churchill Jr, G. A. 1979. A paradigm for developing better measures of marketing constructs. Journal of Marketing Research, 16(1): 64-73.

Cunningham, R. B., \& Sarayrah, Y. K. 1993. Wasta: The hidden force in Middle Eastern society. Westport, CT: Praeger.

Cunningham, R. B., Sarayrah, Y. K., \& Sarayrah, Y. E. 1994. Taming wasta to achieve development. Arab Studies Quarterly, 16(3): 29-41.

Dunfee, T. W., \& Warren, D. E. 2001. Is guanxi ethical? A normative analysis of doing business in China. Journal of Business Ethics, 32(3): 191-204.

Eid, R. 2009. Factors affecting the success of world class manufacturing implementation in less developed countries: The case of Egypt.Journal of Manufacturing Technology Management, 20(7): 989-1008. 
Eid, R. 2015. Integrating Muslim customer perceived value, satisfaction, loyalty and retention in the tourism industry: An empirical study. International Journal of Tourism Research, 17(3): 249-260.

Eid, R., \& El-Gohary, H. 2015. The role of Islamic religiosity on the relationship between perceived value and tourist satisfaction. Tourism Management, 46: 477-488.

El-Said, H., \& Harrigan, J. 2009. 'You reap what you plant': Social networks in the Arab world - The Hashemite Kingdom of Jordan. World Development, 37(7): 1235-1249.

Elsharnouby, T., \& Parsons, E. 2010. A broader concept of relationships: Identifying new forms of consumer-provider interactions in Egyptian financial services.Journal of Marketing Management, 26(13-14): 1367-1388.

Fainshmidt, S., Judge, W. Q., Aguilera, R. V., \& Smith, A. 2018. Varieties of institutional systems: A contextual taxonomy of understudied countries. Journal of World Business, 53(3): 307-322.

Fan, Y. 2002. Ganxi's consequences: Personal gains at social cost. Journal of Business Ethics, 38 (4): $371-380$.

Farquhar, J. D. 2005. Retaining customers in UK financial services: The retailers' tale. The Service Industries Journal, 25(8): 1029-1044.

Farrington, T., Gurran, R., Gori, K., Gorman, K., \& Queenan, G. J. 2017. Corporate social responsibility: Reviewed, rated, revised. International Journal of Contemporary Hospitality Management, 29(1): 30-47.

Flambard-Ruaud, S. 2005. Relationship marketing in emerging economies: Some lessons for the future. Vikalpa, 30(3): 53-64.

Fornell, G., \& Larcker, D. 1981. Evaluating structural equation models with unobservable variables and measurement error. Journal of Marketing Research, 18(1): 39-50.

Geddie, M. W., DeFranco, A. L., \& Geddie, M. F. 2002. From guanxi to customer relationship marketing: How the constructs of guanxi can strengthen CRM in the hospitality industry.Journal of Travel \& Tourism Marketing, 13(3): 19-33.

Geddie, M. W., DeFranco, A. L., \& Geddie, M. F. 2005. A comparison of relationship marketing and guanxi: Its implications for the hospitality industry. International Journal of Contemporary Hospitality Management, 17(7): 614-632.

Geng, R., Mansouri, S. A., Aktas, E., \& Yen, D. A. 2017. The role of guanxi in green supply chain management in Asia's emerging economies: A conceptual framework. Industrial Marketing Management, 63: 1-17.

Gummesson, E. 1999. Total relationship marketing: From the 4ps - product, price, promotion, place - of traditional marketing management to the 30rs - the thirty relationships - of the nez marketing paradigm. Oxford: Butterworth-Heinemann.

Gupta, S., \& Zeithaml, V. 2006. Customer metrics and their impact on financial performance. Marketing Science, 25(6): 718-739.

Hair, J., Black, B., Babin, B., Ralph, A., \& Ronald, T. 2006. Multivariate data analysis, 6th edition. London: Prentice-Hall.

Hofstede, G. 2001. Culture's consequences: Comparing values, behaviors, institutions, and organizations across nations. Thousand Oaks, CA: Sage publications.

Huang, X. 2008. Guanxi networks and job searches in China's emerging labour market: A qualitative investigation. Work, Employment \& Society, 22(3): 467-484.

Hutchings, K., \& Weir, D. 2006a. Guanxi and wasta: A comparison. Thunderbird International Business Revieze, 48(1): 141-156.

Hutchings, K., \& Weir, D. 2006b. Understanding networking in China and the Arab world: Lessons for international managers. Journal of European Industrial Training, 30(4): 272-290.

Hwang, K. 1987. Face and favor: The Chinese power game. American Journal of Sociology, 92 (4): $944-974$.

Hyder, A. S., \& Fregidou-Malama, M. 2009. Services marketing in a cross-cultural environment: The case of Egypt. Journal of Services Marketing, 23(4): 261-271.

Ivens, S., \& Pardo, C. 2007. Are key account relationships different? Empirical results on supplier strategic and customer reactions. Industrial Marketing Management, 36(4): 470-482.

Jacobs, J. 1979. A preliminary model of particularistic ties in Chinese political alliances: Kan-chi'ing and kuan-hsi in a rural Taiwanese township. The China Quarterly, 78: 237-274.

Jia, L., You, S., \& Du, Y. 2012. Chinese context and theoretical contributions to management and organization research: A three-decade review. Management and Organization Revieze, 8 (1): 173-209.

(C) The Author(s), 2021. Published by Cambridge University Press on behalf of The International Association for Chinese Management Research 
Jöreskog, K., \& Sorbom, D. 1982. Recent developments in structural equation modeling. Journal of Marketing Research, 19(4): 404-416.

Kabasakal, H., \& Bodur, M. 2002. Arabic cluster: A bridge between east and west. Jourmal of World Business, 37(1): 40-54.

Keiningham, T. L., Cooil, B., Aksoy, L., Andreassen, T. W., \& Weiner, J. 2007. The value of different customer satisfaction and loyalty metrics in predicting customer retention, recommendation, and share-of-wallet. Managing Service Quality, 17(4): 361-384.

Kienzle, R., \& Shadur, M. 1997. Developments in business networks in East Asia. Management Decision, 35(1): 23-32.

Kiong, T. C., \& Kee, Y. P. 1998. Guanxi bases, ximyong and Chinese business networks. British Journal of Sociology, 49(1): 75-96.

Lee, D., \& Dawes, P. L. 2005. Guanxi, trust, and long-term orientation in Chinese business markets. Journal of International Marketing, 13(2): 28-56.

Lee, L. W., Tang, Y., Yip, L. S., \& Sharma, P. 2017. Managing customer relationships in the emerging markets-guanxi as a driver of Chinese customer loyalty. Journal of Business Research, 86: $356-365$.

Lee, T., \& Jun, J. 2007. Contextual perceived value? Investigating the role of contextual marketing for customer relationship management in a mobile commerce context. Business Process Management Journal, 13(6): 798-814.

Leung, C. W. K., Chan, S. C. F., Chung, F. L., \& Ngai, G. 2011. A probabilistic rating inference framework for mining user preferences from reviews. World Wide Web, 14(2): 187-215.

Li, P. P., Zhou, S. S., Zhou, A. J., \& Yang, Z. 2019. reconceptualizing and redirecting research on guanxi: 'Guan-xi' interaction to form a multicolored Chinese knot. Management and Organization Review, 15(3): 643-677.

Lindell, M. K., \& Whitney, D. J. 2001. Accounting for common method variance in cross-sectional research designs. Journal of Applied Psychology, 86(1): 114.

Little, E., \& Marandi, E. 2003. Relationship marketing management. Singapore: Thomson Learning.

Luo, Y. 2007. Guanxi and business, 2nd Ed. Singapore: World Scientific.

Luo, Y. 1997. Guanxi and performance of foreign-invested enterprises in China: An empirical inquiry. Management International Review, 37(1): 51-70.

Luo, Y., Huang, Y., \& Wang, S. L. 2012. Guanxi and organizational performance: A meta-analysis. Management and Organization Review, 8(1): 139-172.

Mavondo, F. T., \& Rodrigo, E. M. 2001. The effect of relationship dimensions on interpersonal and interorganizational commitment in organizations conducting business between Australia and China. Journal of Business Research, 52(2): 111-121.

Metcalfe, B. D. 2006. Exploring cultural dimensions of gender and management in the Middle East. Thunderbird International Business Reviere, 48(1): 93-107.

Mittal, B., \& Lassar, W. M. 1998. Why do customers switch? The dynamics of satisfaction versus loyalty. Journal of Services Marketing, 12(3): 177-194.

Mohamed, A. A., \& Mohamad, M. S. 2011. The effect of wasta on perceived competence and morality in Egypt. Cross Cultural Management: An International Journal, 18(4): $412-425$.

Mohammed, A., \& Rashid, B. 2018. A conceptual model of corporate social responsibility dimensions, brand image andcustomer satisfaction in Malaysian hotel industry. Kasetsart Journal of Social Sciences, 39(2): 358-364.

Morgan, R. M., \& Hunt, S. D. 1994. The commitment-trust theory of relationship marketing. Journal of Marketing, 58(3): 20-38.

Ndubisi, N. O. 2007. Relationship marketing and customer loyalty. Marketing Intelligence \& Planning, 25(1): 98-106.

Ndubisi, N. O., \& Wah, C. K. 2005. Factorial and discriminant analyses of the underpinnings of relationship marketing and customer satisfaction. International Journal of Bank Marketing, 23(7): 542-557.

Netemeyer, R. G., Bearden, W. O., \& Sharma, S. 2003. Scale development in the social sciences: Issues and applications. Palo Alto, CA: Sage Publications.

Nicholson, C. Y., Compeau, L. D., \& Sethi, R. 2001. The role of interpersonal liking in building trust in long-term channel relationships. Journal of the Academy of Marketing Science, 29(1): 3.

Osland, G. E. 1990. Doing business in China: A framework for cross-cultural understanding. Marketing Intelligence \& Planning, 8(4): 4-14. 
Palmatier, R., Jarvis, C., Bechkoff, J., \& Kardes, F. 2009. The role of customer gratitude in relationship marketing. Journal of Marketing, 73(5): 1-18.

Pawelka, P., \& Boeckh, A. 2004. Patrimonial capitalism: Economic reform and economic order in the Arab world. Germany: University of Tübingen.

Phan, P., Zhou, J., \& Abrahamson, E. 2010. Creativity, innovation, and entrepreneurship in China. Management and Organization Revieze, 6(2):175-194.

Podsakoff, P. M., \& Organ, D. W. 1986. Self-reports in organizational research: Problems and prospects. Journal of Management, 12(4): 531-544.

Podsakoff, P. M., MacKenzie, S. B., Lee, J. Y., \& Podsakoff, N. P. 2003. Common method biases in behavioral research: A critical review of the literature and recommended remedies.Journal of Applied Psychology, 88(5): 879-903.

Reichheld, F. F. 1996. Learning from customer defections. Harvard Business Revieze, 74: 56-70.

Ren, S., \& Chadee, D. 2017. Is guanxi always good for employee self-development in China? Examining non-linear and moderated relationships. Journal of Vocational Behavior, 98: 108-117.

Rudestam, K. E., \& Newton, R. R. 2007. Surviving your dissertation: A comprehensive guide to content and process. London: Sage Publications.

Salaheldin, I. S., \& Eid, R. 2007. The implementation of world class manufacturing techniques in Egyptian manufacturing firms: An empirical study. Journal of Industrial Management and Data Systems, 107(4): 551-566.

Samaha, S. A., Beck, J. T., \& Palmatier, R. W. 2014. The role of culture in international relationship marketing. Journal of Marketing, 78(5): 78-98.

Saunders, M., Lewis, P., \& Thornhill, A. 2012. Research methods for business students (6th ed.). New York, NY: Pearson Education.

Shaalan, A. S., Reast, J., Johnson, D., \& Tourky, M. E. 2013. East meets West: Toward a theoretical model linking guanxi and relationship marketing. Journal of Business Research, 66(12): 2515-2521.

Shaalan, A. S., Weir, D., Reast, J., Johnson, D., \& Tourky, M. 2014. Exploring guanxi-type relationships in the Arab zeorld. Paper presented at the British Academy of Management Conference, Belfast, Northern Ireland, UK.

Sharma, P. 2010. Measuring personal cultural orientations: Scale development and validation. Journal of the Academy of Marketing Science, 38(6): 787-806.

Shou, Z., Guo, R., Zhang, Q., \& Su, C. 2011. The many faces of trust and guanxi behavior: Evidence from marketing channels in China. Industrial Marketing Management, 40(4): 503-509.

Sin, L. Y., Tse, A. C., Yau, O. H., Chow, R. P., Lee, J. S., \& Lau, L. B. 2005. Relationship marketing orientation: Scale development and cross-cultural validation.Journal of Business Research, 58(2): 185-194.

Sin, L. Y., Tse, A. C., Yau, O. H., Lee, J. S., \& Chow, R. 2002. The effect of relationship marketing orientation on business performance in a service-oriented economy. Journal of Services Marketing, 16(7): 656-676.

Smith, J. B., \& Barclay, D. W. 1997. The effects of organizational differences and trust on the effectiveness of selling partner relationships. Journal of Marketing, 61(1): 3-21.

Smith, J. B., \& Barclay, D. W. 1999. Selling partner relationships: The role of interdependence and relative influence. Journal of Personal Selling and Sales Management, 19(4): 21-40.

Smith, P. B., Huang, H. J., Harb, G., \& Torres, C. 2012. How distinctive are indigenous ways of achieving influence? A comparative study of guanxi, wasta, jeitinho, and 'pulling strings'. Journal of Cross-Cultural Psychology, 43(1): 135-150.

Statista. 2020. Market size of the global hotel industry from 2014 to 2018. [Cited 10 August 2020.]Available from URL: https://www.statista.com/statistics/247264/total-revenue-of-theglobal-hotel-industry/\#statisticContainer

Tang, X., Chou, T.J., \& Chen, S. 2008. An empirical study of the effects of guanxi investment on customer loyalty in Chinese market. Frontiers of Business Research in China, 2(1): 98-115.

Trasorras, R., Weinstein, A., \& Abratt, R. 2009. Value, satisfaction, loyalty and retention in professional services. Marketing Intelligence \& Planning, 27(5): 615-632.

Tsang, E. W. 1998. Can guanxi be a source of sustained competitive advantage for doing business in China? Academy of Management Executive, 12(2): 64-73.

Tseng, Y. M. 2007. The impacts of relationship marketing tactics on relationship quality in service industry. The Business Revieze Journal, 7(2): 310-314.

Tucker, H., \& Zhang, J. 2016. On Western-centrism and Chineseness in tourism studies. Annals of Tourism Research, 61: 250-252.

(C) The Author(s), 2021. Published by Cambridge University Press on behalf of The International Association for Chinese Management Research 
UNWTO. 2019. International Tourism Highlights Report, 2019. [Cited 1 August 2020.] Available from URL: https://www.eunwto.org/doi/pdf/10.18111/9789284421152

Wang, G. L. 2007. Guanxi vs. relationship marketing: Exploring underlying differences. Industrial Marketing Management, 36(1): 81-86.

Webster Jr, F. E. 1992. The changing role of marketing in the corporation.Journal of Marketing, 56(4): $1-17$.

Weir, D., \& Hutchings, K. 2005. Cultural embeddedness and contextual constraints: Knowledge sharing in Chinese and Arab cultures. Knozeledge and Process Management, 12(2): 89-98.

Weir, D., Sultan, N., \& Van De Bunt, S. 2016. Wasta: A scourge or a useful management and business practise? In M. Ramady (Ed.), The political economy of wasta: Use and abuse of social capital networking: 23-31. Switzerland: Spring International Publishing.

Weir, D., Sultan, N., \& Van De Bunt, S. 2019. Doing business in the Arab world: Unlocking the potential of wasta. In Globalization and development: 323-341. Cham, Switzerland: Springer.

Wu, W. K., \& Chiu, S. W. 2016. The impact of guanxi positioning on the quality of manufacturerretailer channel relationships: Evidence from Taiwanese SMEs. Journal of Business Research, 69(9): 3398-3405.

Xin, K. R., \& Pearce, J. L. 1996. Guanxi: connections as substitutes for formal institutional support. Academy of Management Joumal, 39(6): 1641-1658.

Yang, M. M., 1988. The modernity of power in the Chinese socialist order. Cultural Anthropology, 3(4): 408-427.

Yang, M. M. 1994. Gifts, favors, and banquets: The art of social relationships in China. Ithaca, NY: Cornell University Press.

Yau, O. H., Lee, J. S., Chow, R. P., Sin, L. Y., \& Alan, C. B. 2000. Relationship marketing the Chinese way. Business Horizons, 43(1):16-24.

Yen, D. A., \& Barnes, B. R. 2011. Analyzing stage and duration of Anglo-Chinese business-to-business relationships. Industrial Marketing Management, 40(3): 346-357.

Yen, D. A., Yu, Q., \& Barnes, B. R. 2007. Focusing on relationship dimensions to improve the quality of Chinese-Western business-to-business exchanges. Total Quality Management and Business Excellence, 18(8): 889-899.

Yen, D. A., Abosag, I., Huang, Y. A., \& Nguyen, B. 2017. Guanxi GRX (ganqing, renqing, xinren) and conflict management in Sino-US business relationships. Industrial Marketing Management, 66(1): 103-114.

Yeung, I. Y. M., \& Tung, R. L. 1996. Achieving business success in Confucian societies: The importance of guanxi (connections). Organizational Dynamics, 25(2): 54-65.

Zeithaml, V. A., Berry, L. L., \& Parasuraman, A. 1996. The behavioral consequences of service quality. Journal of Marketing, 60(2): 31-46.

Zeithaml, V., \& Bitner, M. 1996. Services marketing. New York: McGraw-Hill.

Zhang, C. X., Kimbu, A. N., Lin, P., \& Ngoasong, M. Z. 2020. Guanxi influences on women intrapreneurship. Tourism Management, 81: 104137

Zhang, Y., \& Zhang, Z. 2006. Guanxi and organizational dynamics in China: A link between individual and organizational levels. Journal of Business Ethics, 67(4): 375-392.

Zhao, G., \& Burt, R. 2018. A note on business survival and social networks. Management and Organization Revieze, 14(2): 1-18.

Ahmed Shaalan (Ahmed.Shaalan@zu.ac.ae) is Associate Professor in Marketing at College of Business, Zayed University, Abu Dhabi, UAE. He is best known for his work on relationship marketing and social networks, including Chinese guanxi and Arab wasta. He is also interested in tourism marketing. His research has been published in leading scientific journals such as the Journal of Business Ethics, Fournal of Business Research, Fournal of Sustainable Tourism, and International Fournal of Contemporary Hospitality Management.

Riyad Eid (riyad.aly@uaeu.ac.ae) is Professor of Marketing at United Arab Emirates University, UAE and Tanta University, Egypt. He is the founding and current Editor-in-Chief for the International of Journal Customer Relationship 
Marketing and Management and Editor-in-Chief of the International Fournal of Disruptive Innovation in Government (Emerald Journal funded by the UAE Government Prime Minister's Office). He held various academic positions in the UK and UAE. He has published a significant number of articles in top ranked journals such as the International Fournal of Marketing, Fournal of Travel Research, Tourism Management, and The Service Industries Fournal.

Marwa Tourky (M.Tourky@cranfield.ac.uk) is Associate Professor in Marketing and Brand Management at School of Management, Cranfield University, UK, and Tanta University, Egypt. Her research is focused in areas such as corporate brand, identity, and reputation, communications, and CSR. She is also interested in relationship marketing and networks. Her research has appeared in leading scientific journals such as fournal of Business Research, European Fournal of Marketing and is also the author for the Integrated Marketing Communications book by Macmillan International Higher Education.

Manuscript received: January 12, 2020

Final version accepted: December 13, 2020 (number of revisions - 2) 